\title{
Identifikasi Capaian Indikator Bidang Pengembangan Kognitif Anak Usia 5-6 Tahun Selama Belajar Dari Rumah Di TK PGRI Tanjung Batu
}

\author{
Anggun Karnita ${ }^{1 *}$, Sri Sumarni ${ }^{2}$ \\ ${ }^{1}$ FKIP Universitas Sriwijaya, Palembang, 30128, Indonesia \\ ${ }^{2}$ FKIP Universitas Sriwijaya, Palembang, 30128, Indonesia \\ E-mail: akarnita301@gmail.com ${ }^{1 *}$ ) sri_sumarni@fkip.unsri.ac.id ${ }^{2}$
}

Abstract. Identification of Achievement Indicators in the Cognitive Development Field Children aged 5-6 years while learning from home At TK PGRI Tanjung Batu. This research was conducted with the aim of identifying the proportion of development indicators for children aged 5 to 6 years during the implementation of BDR (learning from home) at TK PGRI Tanjung Batu. This type of research is quantitative quantitative. Observation data through and interviews. The population of this study were children in group $B$ and a sample of 21 children who were selected based on nonprobability techniques. The results showed that the cognitive proportion of children individually included 5 children with the category developing according to expectations (24\%), 1 child with the category developing according to expectations (5\%), 9 children with the category starting to develop (43\%) and 6 children with the category not yet. developing (28\%). The percentage of classical completeness value of 21 children was $28 \%$.

Keywords : development, cognitive, early childhood, learning from home

\begin{abstract}
Abstrak. Identifikasi Capaian Indikator Bidang Pengembangan Kognitif Anak Usia 5-6 Tahun Selama Belajar Dari Rumah Di TK PGRI Tanjung Batu. Penelitian ini dilakukan dengan tujuan untuk mengidentifikasikan persentase indikator perkembangan kognitif anak usia 5 sampai dengan 6 tahun selama pelaksanaan BDR (belajar dari rumah) di TK PGRI Tanjung Batu. Jenis penelitian yang digunakan yaitu kuantitatif deskriptif. Data dikumpulkan melalui observasi dan wawancara. Populasi dari penelitian ini yaitu anak kelompok B dan sampel sebanyak 21 anak yang dipilih berdasarkan teknik nonprobabilitas. Hasil penelitian menujukkan bahwa persentase kemampuan kognitif anak secara individual meliputi $24 \%$ anak ada di kategori berkembang sesuai harapan, $5 \%$ anak di kategori berkembang sesuai harapan, $43 \%$ anak di kategori mulai berkembang dan $28 \%$ anak di kategori belum berkembang. Persentase nilai ketuntasan klasikal dari 21 anak sebesar $28 \%$.
\end{abstract}

Kata Kunci : pengembangan, kognitif, anak usia dini, belajar dari rumah 


\section{PENDAHULUAN}

\section{Teori Kognitif Jean Piaget}

Kognitif adalah usaha untuk mengenali sesuatu melalui kegiatan memperhatikan dengan ketelitian, membayangkan, memperkirakan, menduga serta menilai (Fatimah et al., n.d.). Teori kognitif memiliki pandangan bahwa anak menerima informasi dan pelajaran diawali dengan mengumpulkan, menyimpan dan menyangkutpautkan antara pengetahuan baru dengan pengetahuan yang sudah ia ketahui sebelumnya. Ilmu pengetahuan diperoleh oleh individu melalui proses interaksinya dengan lingkungan secara terus-menerus dan menyeluruh (Parwati, 2018). Demikian juga menurut pendapat Nurhalimah (2020), bahwa kognitif adalah proses berpikir dengan menyangkutpautkan satu peristiwa dengan peristiwa lain dan mampu menilai serta mempertimbangkan berbagai macam keadaan yang diamati dari lingkungan sekitar.

Menurut Piaget (Muri'ah, Wardan, 2020), tahapan perkembangan kognitif anak terbagi menjadi empat. Urutan tahapan ini bersifat tetap untuk semua orang, namun usia kronologis memasuki tahapannya bervariasi. Adapun keempat tahapan tersebut dijelaskan oleh Marinda (2020), antara lain:

a. Sensorimotor

Jenjang ini dialami oleh individu ketika berada di umur 0 sampai dengan 2 tahun ketika anak memiliki refleks naluriah ketika lahir hingga permulaan berpikir simbolik. Anak memperoleh pemahaman mengenai lingkungan pengalaman sensori dengan tindakan fisik.

b. Pra Operasional

Jenjang ini dialami oleh individu ketika berada di umur 2 sampai dengan 7 tahun ketika anak mulai menghubungkan kata dan gambar dalam satu keadaan. Kata dan gambar menandakan bahwa adanya peningkatan berpikir simbolis dan melewati informasi yang anak peroleh dari penggunaan panca indera dan tindakan fisik. Cara berpikir anak pada tahap ini tidak teratur, tidak tetap, dan tidak masuk akal.

c. Operasional Konkret

Jenjang ini dialami oleh individu ketika berada di umur 7 hingga umur 11 tahun. Anak akan berpikir sesuai dengan logika tentang kejadian yang benar terjadi.

d. Operasional Formal

Jenjang ini dialami oleh individu ketika berada di umur 11 tahun hingga dewasa. Kemampuan berpikir sudah lebih matang dan masuk akal.

Pendapat Jean Piaget, anak yang berada pada rentang usia 4 samapi dengan 7 tahun berada di bawah subtahap intuitif tahap pra-operasional. Kecerdasan intuitif adalah proses kognitif yang spontan berdasarkan skema tertentu. Intuitif adalah kemampuan dalam memunculkan dan menyeleksi konsep skema yang sudah diketahui yang kemudian di respon secara spontan dengan tingkat akurasi yang tinggi (Habibullah, 2020). Karakteristik anak yang berada pada sub-tahap intuitif ini ditandai dengan kemampuan mengelompokkan sesuatu berdasarkan warna atau ukuran (Rosmayanti, 2019). Sedangkan menurut Parwati (2018) karakteristik anak yang berada pada subtahap intuitif antara lain:

1. Anak mampu mengklasifikasikan objek meskipun tidak disadari olehnya.

2. Anak sudah mulaipaham tentang hubungan sebab akibat yang terjadi sesuai dengan logika. 
3. Anak mampu mengerjakan sesuatu dengan ide yang ia miliki.

4. Anak mengetahui bahwa meskipun diklasifikasikan secara berulang-ulang namun jumlah objek akan tetap sama.

\section{Belajar dari Rumah melalui Pembelajaran Jarak Jauh \\ Kementrian Pendidikan dan}

Kebudayaan mengeluarkan peraturan bahwa pendidikan di Indonesia dilaksanakan di rumah masing-masing. Pembelajaran memiliki arti yang tidak sama dengan belajar. Pembelajaran adalah aktivitas belajar dengan fasilitas yang diberikan oleh guru guna meningkatkan perkembangan kognitif dan daya pikir sehingga anak memeroleh pengetahun yang baru. Pembelajaran adalah proses saling berhungan untuk berbagi informasi oleh guru kepada anak agar anak mendapatkan pengalaman, sikap dan keterampilan (Saifulloh \& Darwis, n.d.). Pembelajaran dalam jaringan merupakan proses belajar bertatap muka dengan terhubung ke internet, misalnya melalui zoom (Aziza \& Yunus, 2020).

Pembelajaran dalam jaringan adalah salah satu metode dalam belajar melalui penggunaan internet seperti zoom, grup whatsapp dan lain sebagainya (Malyana, 2020). Pembelajaran ini bertujuan untuk memberikan layanan belajar yang berkualitas secara dalam jaringan bersifat kuat dan terbuka untuk menjangkau siswa yang lebih banyak dan luas (Chusna, Utami, 2020).

Pembelajaran luar jaringan adalah aktivitas belajar yang tidak terhubung dengan internet, misalnya melalui buku atau belajar langsung di ruang sekolah. Selama masa pandemi ini, pembelajaran luring dilakukan dengan aktivitas menonton TVRI kemudian anak mengumpulkan karyanya dalam bentuk dokumen (Malyana, 2020).
Interaksi orang tua dan anak sangatlah penting demi keberlangsungan pembelajaran selama masa pandemi COVID-19. Ada dua jenis aktivitas yang dapat dilakukan oleh orang tua kepada anak selama pembelajaran jarak jauh, yaitu secara langsung dan tidak langsung. Secara langsung, orang tua membersamai anak dalam pembelajaran jarak jauh yang diberikan oleh guru. Sedangkan secara tidak langsung, orang tua dapat menjadi fasilitator dalam terlaksananya pembelajaran (Putro, Amri, Wulandari, \& Kurniawan, 2020).

Interaksi yang baik antara orang tua dan anak mampu meningkatkan daya kreasi, imajinasi serta membantu anak sehingga lebih terarah dalam belajar. Ada beberapa alasan yang mendasari pentingnya keterlibatan orang tua dalam pendidikan anak yaitu, berkomunikasi dengan baik bersama guru tentang kegiatan yang dilakukan anak, selain itu orang tua juga dapat berkontribusi terhadap pencapaian tugas perkembangan anak (Yulianingsih, 2021). Orang tua merupakan seorang yang intensitas pertemuannya paling banyak dengan anak, sehingga pendampingan orang tua sangat diperlukan untuk berkoordinasi dengan guru selama belajar dari rumah. Orang tua seharusnya mengajarkan anak untuk bisa menyelesaikan permasalahannya secara mandiri. Apabila anak terbiasa dibantu maka anak akan menggantungkan hidupnya pada orang lain sehingga orang tua harus melatih kemadirian pada anak. Kemandirian berkaitan erat dengan kedisiplinan (Pangastuti, 2020). Ada beberapa karakteristik pembelajaran dalam jaringan yaitu constructivism, social constructivism, community of learners, virtual class, perilaku interaktivitas, kemandirian, aksesibilitas serta pengayaan (Ditjen GKT, 2016). 
Jurnal Pendidikan Anak, April 2021, p : 37-42

E-ISSN: 2580-9504

P-ISSN: 2775-4367

\section{METODE}

Desain penelitian yang digunakan yaitu kuantitatif deskriptif. Penelitian dilaksanakan di TK PGRI Tanjung Batu, Ogan Ilir. Penelitian dilaksanakan pada semester genap tahun ajaran 2020-2021.

Teknik pengumpulan sampel menggunakan teknik nonprobabilitas atau yang biasa disebut dengan purposive sampling. Sampel yang dipilih sebanyak 21 anak pada kelompok B1 dan B2.

Teknik pengumpulan data menggunakan observasi dan wawancara. Peneliti mengamati perilaku anak melalui video karena pembelajaran yang dilaksanakan secara jarak jauh.

Pengembangan kognitif anak diukur dengan menggunakan instrumen yang dibuat oleh peneliti sendiri. Instrumen diuji validitas dan reliabilitasnya. Uji validitas dengan product moment dan uji reliabilitas dengan alpha cornbach's. Instrumen terdiri dari 8 butir pertanyaan dengan 4 kategori skor $(4=\mathrm{BSB}, 3=\mathrm{BSH}, 2=\mathrm{MB}$ dan $\quad B B=1)$. Hasil uji reliabilitas menujukkan bahwa instrumen reliabel dengan nilai Cron bach Alpha sebesar 0,792 .

\section{HASIL DAN PEMBAHASAN}

Dari hasil analisis diketahui persentase pengembangan kognitif anak pada 4 kategori yaitu $24 \%$ anak ada di kategori berkembang sesuai harapan, 5\% anak berada di kategori berkembang sesuai harapan, $43 \%$ anak di kategori mulai berkembang dan $28 \%$ anak di kategori belum berkembang yang dianalisis dengan rumus berikut:

Skor diubah menjadi nilai dengan rumus,

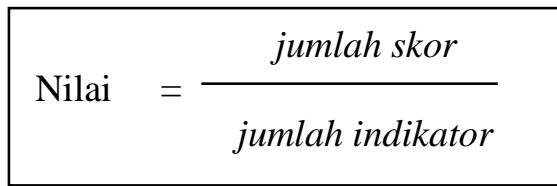

Sumber : (Dimyati, 2016)
Vol. 7 No. 1 Tahun 2021

DOI:

Ketuntasan individual dihitung dengan rumus,

Persentase $=\frac{\text { skor yang diperoleh }}{\text { skor maksimum }} \times 100 \%$

Sumber: (Lestari, Ariani, Gumay, 2018)

Tabel 4.12 Kriteria Skor

\begin{tabular}{ccc}
\hline No & Skor & Kriteria \\
\hline $\mathbf{1}$ & $85,01-100,00 \%$ & BSB \\
$\mathbf{2}$ & $70,01-85,00 \%$ & BSH \\
$\mathbf{3}$ & $50,01-70,00 \%$ & MB \\
$\mathbf{4}$ & $01,00-50,00 \%$ & BB \\
\hline
\end{tabular}

Sumber : (Fatmawati, 2016)

Tabel 4.13 Hasil Observasi

\begin{tabular}{cccc}
\hline No & Skor & Frekuensi & Kriteria \\
\hline $\mathbf{1}$ & $85,01-$ & 5 Anak & BSB \\
& $100,00 \%$ & & \\
$\mathbf{2}$ & $70,01-$ & 1 Anak & BSH \\
& $85,00 \%$ & & \\
$\mathbf{3}$ & $50,01-$ & 9 Anak & MB \\
& $70,00 \%$ & & \\
$\mathbf{4}$ & $01,00-$ & 6 Anak & BB \\
& $50,00 \%$ & & \\
\hline
\end{tabular}

Sedangkan ketuntasan klasikal yaitu:

Persentase $=\frac{6}{21} \times 100 \%$

Melalui rumus tersebut, diperoleh presentase nilai ketuntasan klasikal sebesar $28 \%$ dari $100 \%$.

\section{Pembahasan}

Pandemi COVID-19 ini memberikan dampak jangka panjang di dunia pendidikan yaitu masalah keadilan dan peningkatan ketidaksetaraan antar kelompok masyarakat dan antar daerah di Indonesia (Pangastuti, 2020). Pembelajaran jarak jauh melalui belajar dari rumah ini merupakan kejutan yang besar bagi seluruh keluarga di Indonesia, apalagi bagi orang tua yang memiliki produktivitas yang tinggi. Kebijakan pemerintah dalam pelaksaan belajar dari 
rumah ini menjadikan orang tua banyak terlibat dalam kegiatan pendampingan anak. Dalam hal ini orang tua berperan sebagai motivator, fasilitator, pengajar sekaligus pengawas bagi anak (Yulianingsih, 2020). Awalnya orang tua perperan dalam membimbing sikap dan keterampilan mendasar anak, namun kemudian perannya meluas yaitu sebagai pembimbing akademik (Kurniati, 2021). Dukungan serta fasilitas orang tua sangat dibutuhkan bagi anak karena anak usia dini belum mandiri secara seutuhnya. Namun, kurangnya pemahaman orang tua terhadap pemanfaatan teknologi dalam pembelajaran online menjadi salah satu kendala. Berbagai permasalahan muncul selama pelaksanaan belajar dari rumah ini, mulai dari pemahaman penggunaan IT yang terbatas, kuota internet dan permasalahan lainnya (Fujiawati, 2020). Faktor lain yang menyebabkan orang tua/wali anak tidak mendampingi yaitu karena tidak semua orang tua mau untuk membuatkan anak lembar belajarnya berdasarkan instruksi guru dari grup whatsapp. Namun hal ini telah menjadi pertimbangan oleh pihak sekolah sehingga membuat kebijakan baru untuk membuat LKPD anak selama 1 minggu yang diambil dan dikumpulkan kembali setiap hari sabtu oleh orang tua/wali anak. Solusi ini memberikan dampak positif terhadap peningkatan jumlah anak yang mengikuti pembelajaran jarak jauh meskipun tidak memberikan dampak yang signifikan terhadap ketercapaian perkembangan kognitif anak.

\section{SIMPULAN DAN SARAN}

Dari penelitian yang dilakukan di TK PGRI Tanjung Batu, perkembangan kognitif anak usia 5 sampai dengan 6 tahun selama belajar dari rumah dapat ditarik kesimpulannya yaitu: Pertama, presentase kemampuan kognitif anak secara individual meliputi 5 anak di kategori berkembang sesuai harapan
(24\%), 1 anak di kategori berkembang sesuai harapan (5\%), 9 anak di kategori mulai berkembang (43\%) dan 6 anak berada di kategori belum berkembang (28\%). Kedua, Presentase nilai ketuntasan klasikal dari 21 anak sebesar $28 \%$.

Berdasarkan simpulan di atas, peneliti berharap peneliti selanjutnya dapat melakukan penelitian dengan populasi yang lebih besar sehingga simpulan yang didapatkanpun akan lebih banyak pula.

\section{REFERENSI}

Aziza, F. N., Yunus, M. (2020). Peran Orang Tua Dalam Membimbing Anak Pada Masa Study From Home Selama Pandemi COVID 19. Konferensi Nasional Pendidikan, 19-21.

Chusna, Puji Asmaul. (2020). Dampak Pandemi COVID-19 terhadap Peran Orang Tua dan Guru dalam Meningkatkan Kualitas Pembelajaran Daring Anak Usia Sekolah Dasar. Premiere. 2(2).

Dimyati, Johni. (2016). Pembelajaran Terpadu untuk TK/RA dan SD. Jakarta: Kencana.

Ditjen GTK. (2016). Petunjuk Teknis Program Peningkatan Guru Pembelajar Moda Dalam Jaring (Daring).

Fatimah, A., Rosidah, L., Kusumawardani, R., Maryani, K., Rosmilawati, I., \& Kurniawati, Y. (n.d.). SEMINAR DIGITAL.

Fatmawati, Agustina. (2016). Pengembangan Perangkat Pembelajaran Konsep Pencemaran Lingkungan Menggunakan Model Pembelajaran Berdasarkan Masalah Untuk SMA Kelas X. EduSains. 4(2).

Fujiawati, Fuja Siti. (2020). Pemanfaatan Teknologi untuk Pendidikan Anak Usia Dini di Masa Pandemi COVID-19. Prosiding Seminar 
Nasional Pendidikan FKIP. 3(1).

Habibullah, dkk. (2020). Karakteristik Psikologis Siswa dalam Pembelajaran Matematika ditinjau dari Kecerdasan Intuitif dan Reflektif. Jurnal Karya Abdi. 1(1).

Kurniati, Euis., dkk. (2021). Analisis Peran Orang Tua dalam Mendampingi Anak di Masa Pandemi COVID-19. Jurnal Obsesi: Jurnal Pendidikan Anak Usia Dini. 5(1).

Lestari, Wulan Muji., dkk. (2018). Pengembangan Bahan Ajar Fisika Berbasis Scientific Approach. SPEJ. 2(1).

Malyana, Andasia. (2020). Pelaksanaan Pembelajaran Daring dan Luring dengan Metode Bimbingan Berkelanjutan pada Guru Sekolah Dasar di Teluk Betung Utara Bandar Lampung. Jurnal Ilmiah Pendidikan Dasar Indonesia. 2(1): 67-76.

Marinda, Leny. (2020). Teori Perkembangan Kognitif Jean Piaget dan Problematikanya pada Anak Usia Sekolah Dasar. Jurnal Kajian Perempuan \& Keislaman. 13(1).

Muri'ah, Siti., \& Wardan, Khusnul. (2020). Psikologi Perkembangan Anak dan Remaja. Literasi Nusantara.

Nurhalimah, dkk. (2020). Meningkatkan Kemampuan Kognitif dalam Menegenal Warna melalui Bermain Media Penjepit Baju pada Anak KB Adzkyah Bangkinang Kota secara BDR. JOTE. 2(1).

Pangastuti, Ratna., dkk. (2020). Pengaruh Pendampingan Orangtua Terhadap Kemandirian dan Tanggung Jawab Anak Selama Belajar dari Rumah. JECED: Journal of Early Childhood Education and Development. 2(2).

Parwati, Ni Nyoman., Suryawan, I Putu Pasek., \& Apsari, Ratih Ayu.
(2018). Belajar dan Pembelajaran. Depok: PT Rajagrafindo Persada.

Putro, K. Z., Amri, M. A., Wulandari, N., \& Kurniawan, D. (2020). Pola Interaksi Anak dan Orangtua Selama Kebijakan Pembelajaran di Rumah. Fitrah: Journal of Islamic Education (FJIE), 1(1), 125-140.

Saifulloh, A. M., \& Darwis, M. (n.d.). Dalam Meningkatkan Efektivitas Proses Belajar Mengajar Di Masa Pandemi COVID-19.

Yulianingsih, Wiwin. dkk. (2021). Keterlibatan Orang Tua dalam Pendampingan Belajar Anak selama Masa Pandemi Covid-19. Jurnal Obsesi: Jurnal Pendidikan Anak Usia Dini. 5(2): 1138-1150. 